\title{
PERTANGGUNGJAWABAN TINDAK PIDANA PENGEDAR GANJA YANG DILAKUKAN OLEHANAK (BERDASARKAN PUTUSAN No. 10/PID.SUS.ANAK/2015/PN.STB
}

\author{
Oleh : \\ Bella Khairunnisa ${ }^{1)}$, \\ Joni Firdaus Ginting 2), \\ Rini Damayanti Sijabat ${ }^{3)}$, \\ Rahmayanti ${ }^{4)}$ \\ Universitas Prima Indonesia, Medan 1,2,3,4) \\ E-mail : \\ Bellakhairunnisa08@gmail.com ${ }^{1)}$ \\ Jonifirdausginting993@gmail.com ${ }^{2)}$ \\ Rinisyanas@gmail.com ${ }^{3)}$ \\ $\underline{\text { Rahmayanti888@yahoo.com }}^{4)}$
}

\begin{abstract}
ABSTRACK
Government policy in providing protection to children, especially in the crime of cannabis dealers becomes very important. Because children are the next generation to continue the nation's development. There are 2 factors that cause this crime, namely external factors (free will, curiosity) and internal factors (economic conditions and the surrounding environment). Regulations regarding this criminal act are regulated in article 6 Number 35 of 2009 concerning narcotics, governing criminal offenses, regarding specific criminal sanctions as well as the types of sanctions and the length of the crime. In this case, the judge's policy should not be based too much on Law Number 11 of 2012 concerning the juvenile justice system, which continues to interpret the existing law. And the government should provide the assistance of a supervisory body, namely the Special Child Development Institute. and create educational and coaching programs that are supervised by the Penitentiary.
\end{abstract}

Keywords : Policy, Narcotics, Accountability

\begin{abstract}
ABSTRAK
Kebijakan pemerintah dalam memberikan perlidungan kepada anak khususnya dalam tindak pidana pengedar ganja menjadi hal yang sangat penting. Karena anak merupakan generasi penerus bangsa untuk meneruskan pembangunan bangsa. Ada 2 faktor yang menyebabkan tindak pidana ini yaitu faktor eksternal (kehendak ingin bebas, rasa ingin tahu) dan faktor internal (keadaan perekonomian dan akibat lingkungan sekitarnya). Pengaturan mengenai tindak pidana ini diatur didalam pasal 6 Nomor 35 tahun 2009 tentang narkotika,diatur mengenai tindak pidana, mengenai sanksi pidana khusus serta jenis sanksi dan lamanya pidana. Dalam hal ini kebijakan hakim tidak boleh terlalu berpatokan
\end{abstract}


terhadap UU Nomor 11 tahun 2012 tentang sistem peradilan anak tetap melakukan penafsiran terhadap undang-undang yang sudah ada. Dan pemerintah sebaiknya memberikan bantuan badan pengawas yaitu Lembaga Pembinaan Khusus Anak. dan membuat program pendidikan dan pembinaan yang diawasi oleh Balai Pemasyarakatan.

Kata Kunci : Kebijakan, Narkotika, Pertanggungjawaban

\section{PENDAHULUAN}

Napza merupakan gabungan singkatan dari segala jenis narkotika, psikotropika, zat adiktif, $\mathrm{d}$ a $\mathrm{n}$ alkohol. Napza sering kali disebut dengan istilah "Narkoba" istilah untuk narkotika dan obat berbahaya. Secara etimologi Narkotika berasal dari bahasa Yunani yaitu Narkoum, yang artinya melumpuhkan serta membuat mati rasa. Sedangkan dalam bahasa inggris Narkotika banyak mengarah ke obat dimana mampu menyebabkan penggunaannya kecanduan. Zat yang menimbulkan beberapa pengaruh tertentu bagi penggunananya disebut Narkotika, cara yang digunakan umumnya dengan memasukan obat tersebut kedalam tubuhnya secara langsung maupun dengan bantuan alat, pengaruh yang ditimbulkan berupa pembiasaan, hilangnya rasa sakit, semangat, rangsangan, dan halusinasi (Juliana dan Sutrisna, 2018:1).

Narkotika dapat digunakan dan diedarkan apabila mengikuti prosedur dan aturan yang sudah di tetapkan pemerintah mengenai peredaran narkotika. Undang- Undang Narkotika menyebutkan bahwa yang dapat menjadi penyalur narkotika adalah Imp ortir dan eksportir, farmasi, dan sarana penyimpan, pedagang besar, sediaan farmasi dan pemerintah. Setiap pihak yang menjadi enyalur harus memiliki izin khusus penyalur narkotika dari Menteri Kesehatan (Suprosmono, 2017:174).

Dalam perkembangan di era globalisasi saat ini tentu manfaatnya telah dirasakan oleh semua orang, dimana dapat dilihat dengan munculn ya teknologi- teknologi canggih kini membuat setiap orang dapat melakukan berbagai hal dengan lebih mudah dan lebih praktis, tentunya hal ini cukup memberikan harapan yang lebih baik bagi masyarakat dan bangsa. Namun disisi lain penyalahgunaan narkotika oleh generasi muda menjadi sisi lain yang memprihatinkan, baik mengkonsumsi maupun mengedarkannya.

Perederan gelap narkotika di Indonesia saat ini sudah sangat mengkhawatirkan, dapat dilihat saat ini banyak berita di televisi tentang peredaran gelap narkotika. Kepolisian Badan Narkotika Nasional sering melakukan penggerebekan terhadap berbagai objek yang dianggap sebagai sarang bahkan pabrik-pabrik yang ada, menunjukkan bahwa Indonesia bukan hanya sebagai transitatau. Tujuan pengiriman narkotika, tetapi saat ini mulai menjadi produsen narkotika (Salomo Ginting, 2015:2).

Masalah ini menjadi sangat memprihatinkan dimana para oknumoknum yang tidak bertanggung jawab sering menjadikan anak sebagai perantara untuk melancarkan bisnis perdagangan gelap narkotika dengan cara mengajak kerja sama untuk mengedarkan narkotika dan memberikan upah yang menggiurkan sebagai imbalannya. Di Indonesia orang yang cenderung lebih sering menggunakan ganja adalah pengedar dan pemakaian 
narkoba, hal ini disebabkan harganya yang lebih murah dari narkoba lain, mudah didapatkan, Serta di produksi, jenis narkoba ini mempunyai penggunaanya lebih praktis dan cepat (Juliana dan Sutrisna, 2018:9). Pada umumnya orang yang bermaksud melarikan diri dari kenyataan melakukan cara nya melalui menghisap narkotika jenis ganja ini dengan tujuan, ingin membebaskan diri dari beban fikiran yang sedang kusut, ingin melupakan masalah dan kondisi di sekitarnya serta memperoleh kebahagiaan semu, pelarian inilah yang akan menjerumuskan seseorang kedalam dunia khayal sampai padagangguan jiwa tanpa disadari (Hawari, 2017:41).

\section{TINJAUAN PUSTAKA}

Terkait narkotika tentunya hal in $\mathrm{i}$ harus diperhatikan oleh pemerintah dan masyarakat dengan serius, karena apabila peredaran dan penyalahgu naan narkotika terus merajalela di lapisan masayarakat terlebih pada anak, hal in i akan membawa suatu angsa menjadi bangsa yang sakit. Jika hal ini terus berlanjut maka negara kita akan rapuh karena ketahanan nasional merosot dimana terganggunya tata kehidupan masayarakat dan berdampak pada malapetaka yaitu runtuhnya suatu Bangsa Negara. Pemerintah sudah mengambil kebijakan membuat aturan hukum dan sanksi hukum yang bertujuan untuk menurunkan angka tindak pidana penyalahgunaan narkotika. Selain itu, pemerintah juga telah berhasil menyusun dan mengesahkan UndangUndang nomor 35 tahun 2009 tentang narkotika pada tanggal 14 September 2009 yang merupakan peny em purnaan dari Undang-Undang nomor 22 tahun 1997 yang karena dinilai biak secara kualitatif maupun secara kuantitatif terhadap peredaran dan penyalahgunaan narkotika kurang memberikan efek jera ataupun mengurangi tingkatt pencegahan (Setiyawati, 2015:61).
Indonesia adalah Negara hukum dan seluruh masyarakat Indonesia tentu sudah mengetahui hal ini. Di Indonesia ditetapkan hukum tertulis ataupun tidak tertulis yang diungkapkan dalam bentuk norma kehidupan sehari-hari, sehingga setiap WNI diwajibkan mengikuti dan taat atas segala aturan yang ditetapkan. Tid ak peduli rakyat kecil, pengusah a maupun pejabat tinggi juga wajib taat pada hukum, wajib berlandaskan hukum yang berlaku Segala tindak tanduk maupun perbuatan yang dilakukan di dalam Negara Indonesia (Supramono, 2017:6).

Oleh karena itu apabila terjadi suatu tindak pidana atau pelanggaran hukum maka diselesaikan secara hukum untuk mempertanggungjawabkan atas pelanggaran hukum yang dilakukakan. Pertanggungjawaban seseorang terhadap tindak pidana yang dilakukannya disebut dengan pertanggungjawaban pidana. Artinya pertanggung jawaban pidana dilakukan karena seseorang telah melakukan tindak pidana seseorang. Terkait dengan Maraknya permasalahan anak yang berkonflik dengan hukum sangatlah meresahkan masyarakat, mengingat ketika seorang anak yang masih di bawah umur harus berha dapan dengan hukum untuk mempertanggungjawabkan atas perbuatan tindak pidana yang dilakukannya.

Berdasarkan dari latar belakang diatas maka rumusan masalah dalam penelitian ini adalah sebagai berikut :

1. Bagaimana faktor-faktor yang menyebabkan tindak pidana pengedar ganja yang dilakukan oleh anak?

2. Bagaimana upaya hukum yang diberikan pada anak mengenai tindak pidana pengedar ganja?

3. Bagaimana pertimbangan hakim terhadap tindak pidana pengedar ganja yang dilakukan oleh anak melalui studi kasus putusan : No. 
10. Pid. Sus. Anak/ 2015/ PN. STB?

\section{METODE PELAKSANAAN}

Metode hukum yang digunakan dalampenulisan ini adalah metode penelitian Yuridis normatif dengan mengkaji segala pokok permasalahan yang telah ditentukan dan menjadi ruang lingkup masalah sebagaimana di paparkan diatas. Melalui pendekatan yuridis normative peneliti akan melakukan telaah atau analisis terhadap teori-teori, asas hukum, konsep dan badan hukum utama serta perundang-undangan yang dinilai berhubungan dengan penelitian. Atau sering kali disebut dengan penelitian yang menggunakan pendekatan kepustaaan karena mempelajari buku-buku dan dokumen yang berhubungan dengan kasus y ang akan diteliti.

\section{a. Sumber Bahan Hukum}

Dalam penulisan ini maka sumber bahan-bahan hukum yang ak an diperlukan dalam penelitian ini adalah sebagai berikut:

\section{b. Bahan Hukum Primer :}

Bahan hukum primer yaitu bahanbahan hukum yang mengikat satu sama lainnya. Bahan hukum yang digu nakan dalam penelitian ini terdiri dari peraturan perundang- undangan yaitu:
a. Undang-Undang Dasar Negara Republik Indonesia Tahun 1945.
b. Undang-Undang Nomor 35 Tahun 2009 tentang Narkotika.
c. Undang-Undang Nomor 11 tahun 2012 tenang peradilan pidana anak.
d. Peraturan Perundang- Undangan lain yang terkait.
e. Studi Putusan

No. 10/Pid.Sus.Anak/2015/Pn.Stb

c. Bahan Hukum Sekunder

Salah satu bahan hukum dalam penelitian ini adalah bahan y ang ada hubungannya dengan topik untuk dibahas seperti jurnal-jurnal hukum, dan buku karangan sarjana atau ahli.

\section{d. Bahan Hukum Tersier}

Dalam penulisan ini juga

diperlukan adanya bahan hukum tersier berupa kamus besar bahasa Indonesia dan kamus hukum untuk mendukung bahn hukum primer dan sekunder sehingga dapat membantu memberikan pemahaman bagi bahan hukum primer dan sekunder.

\section{e. Teknik Pengumpulan Bahan}

Dalam penelitian ini, penelitimenggunakan studi pustaka, peneliti mengumpulkan dan menulu suri pustaka, literature, majalah, hasil penelitian, majalah ilmiah serta jurnaal ilmiah. Pengumpulan data yang dilakukan dalam penelitian ini dengan menggunakan hukum normatif yang merupakan suatu metode penelitian hukum yang diilakukan untuk meneliti bahan hukum pustaka dan data sekunder.

\section{f. Analisis Bahan Hukum}

Dalam menganalisis bahan hukum peneliti melakukan analisa secara kualitatif. Dengan cara mendeskripsikan hasil data, ataupun fakta yang diperoleh dari penelitian, kemudian juga melakukan interpretasi, pengetahuan umum dan evaluasi. Peneliti kemudian menganalisis data dengan metode induktif, dengan cara melakukan studi cara berfikir yang telah didasarkan fakta secara umum kemudian peneliti melanjutkan dengan menyimpulkan secara khusus hingga akhirnya dapat memberikan saran-saran, serta data yang telah diolah tersebut kemudian dianalisis dengan menggunakan cara menginterprestasikan 
data dan memaparkannya dalam bentuk kalimat untuk menjawab pada bab- bab selanjutnya.

\section{HASIL DAN PEMBAHASAN}

\section{a. Faktor-Faktor \\ Menyebabkan Tindak \\ Pengedar Ganja Yang Dilakukan \\ Oleh Anak}

Masih banyak anak dan remaja mengetahui musuh nomor satunya, yaitu Narkotika. Narkotika sangat berbahaya bagi anak dan remaja seehingga diseebut dengan musuh nomor satu, . Hal ini dapat dibuktik an dengan semakin banyak remaja yang terjerat dalam kasus narkotika. Keberadaan generasi muda yang sangat diharapkan oleh bangsa akan menjadi ancaman akibat Ketidaktahuan anak dan remaja tentang bahaya narkotika Saat sekarang ini jenis narkotika sangat mudah didapatkan dan sering pula anak di dapat menjdi seorang bandar narkotika. Oleh karena itu Dalam upaya penanggulanganya, masyarakat mempunyai sangat banyak kesempatan untuk dapat berperan serta dalam membantu upaya pencegahan dan pemberantasaan penyalahgunaan dan perederan gelap narkotika. Terja dinya penggunaan narkotika dipengaruhi beberapa faktor dimana faktor dalam diri seorang pecandu narkotika yang meliputi faktor kecerdasan, jenis kelamin serta semua masalah yang dihadapinya.

Secara keseluruhan, umumnya faktor-faktor yang menyebabkann terjadinya banyak tindak pidana narkotika bisa dikelompokkan menjadi

\section{Faktor Internal}

Faktor internal adalah faktor yang berasal dari masyarakat sendiri sehingga mengakibatkan terjadinya perubahan sosial pada penduduk sekitarnya dan dapat mengakibatkan pemberontakan.

a. Individu

Faktor tersendiri adalah rasa ingin untuk coba-coba dikarenakan penasaran, keinginan nya untuk bersenang-senang, keingintahuan nya sangat besar dan upaya untuk menurunkan berat badan dan ketidakmampuan menyesuaikan diri dengan orang lain atau lingkungan

\section{b. Keluarga}

Keluarga adalah basis pertama yang membentuk karakter anak. Anak meniruh tingkah laku orang tuanya. Faktor pecentus berasal dari kurangnya komunikasi dengan orang tua, orang tua terlalu mengatur dan menuntut anak berprestasi dan kurangnya keharmonisan

c. Faktor agama

Agama merupakan unsur pokok dalam manusia yang kebutuhannnya spritual yang harus dipenuhi. Dan sebagaimana agama sebagai kontrol utama bagi lembaga keagamaan.

\section{Faktor Eksternal}

Faktor eksternal adalah faktor yang menyebakan perubahan yang asalnya dari lingkungan sekitarnya atau dari masyarakat. Faktor ini berasal dari faktor alam sehingga mempengaruhi kebudayaan masyarakat sekitarnya.

\section{a. Keadaan ekonomi}

Dalam hal ini kondisi ekonomi pada dasarnya dapat digolongkan dalam 2 (dua) hal yaitu keadaan ekonomi yang baik dan keadaan ekonomi yang buruk atau miskin. Dalam hal keadaan ekonomi yang baik maka orang-orang akan dengan mudah mencapai atau memenuhi kebutuhannya baik jasmani maupun rohaninya dengan mudah.

\section{b. Pergaulan/lingkungan}

Biasanya pergaulan yang terdiri dari lingkungan tempat tinggal, atau pun lingkungan sekolah, tempat kerja dan lingkungan lainnya. Keseluruhan 
lingkungan ini bisa memberikan pengaruh yang berdampak negatif kepada seseorang.

\section{c. Kemudahan}

Kemudahan merupakan banyaknya beredar berbagai macam jenis narkotika dimasyarakat luas, maka peluang terjadinya tindak pidananarkotika semakin besar.

\section{d. Kurangnya pengawasan}

Dalam hal iniyang dimaksudkan dengan pengawasan ialah pengedalian diri terhadap persediaan narkotika, penggunaan, dan peredarannya. Oleh karena itu peranan penting untuk membatasi semakin banyak peredaran, produksi, dan pemakaian narkotika dikalangan masyarakat dipegang oleh pemerintah.

\section{e. Ketidaksenangan terhadap} keadaan sosial.

seseorang yang sedang mengalami permasalahan atau pemikiran yang berat karena faktor keadaan sosial sehingga narkotika lah yang dijadikan sebagai sarana untuk melepaskan diri dari permasalahan tersebut, meskipun hanya untuk waktu yang singkat.

\section{b. Upaya Hukum Terhadap Tindak Pidana Pengedar Ganja Yang Dilakukan Oleh Anak}

Upaya hukum sangat dip erlukan untuk mengatur permasalahan ini. Semua hukum hukum bertujuan menciptakan ketertiban dan kenyamanan didalam pergaulan bermasyarakat. Peredaran narkotika dimasyarakat ini sudah seharusnya mendapatkan perhatian yang khusus oleh pemerin tah khususnya instansi-instansi pemerintah yang bertugas mencegah terjadinya peredaran narkotika. Pemerintah dapat meningkatkan kerjasama dengan lembaga-lembaga masyarakat dalam peredaran narkotika yang mewujudkan masyarakat bebas dari peredaran dan penyalahgunaan narkotika.
Perlindungan terhadap anak benarbenar dilakukan dengan segala aspek kehidupan yang termasuk didalam peradilan pidana anak. Peradilan pidana anak, menegakkan hak-hak anak baik secara tersangaka, terdakwa maupun sebagai narapidana (Maidun, 2014:121). Penanggulangan dan pencegahan y ang dapat dilakukan saat ini harus diprioritaskan yang terpadu. Tindakantindakan hukum dapat dijatuhkan secara maksimum dan berat. Hal ini pelanggar hukum mendapatkan efek jera dan tidakakan mengulagi kesalahanny a dan masyarakat tidak lagi melakukan dan berbuat seperti itu. Pengamatan saat ini terhadap bahaya pengedar/ pengguna narkotika (golongan I) dikalangan remaja secara benar dan dan ada sebelumnya, hal ini untuk tuntas serta berkesinambungan didalam tindakan tegas dan tidak pandnag bulu bagi semua yang melanggar dan yang pengedar narkotika (golongan I).

Upaya hukum yang harus dilakukan oleh aparat kepolisian dengan bantuan masyarakat dalam menanggulangi kejahatan penyalahgunaan narkotika adalah sebagai berikut;

\section{Upaya Preventif}

Upaya preventif adalah upaya yang harus dilkaukan secara sistematis, terarah dan terpadu dengan tujuan menjaga agar peredaran penyalahgunaan narkotika yang melibatkan anak. Upaya pencegahan ini dilakukan supaya tindakan dengan mengurangi pengaruhnya terhadap aspek kehid upan lain.

\section{Upaya Refresif}

Upaya refresif merupakan kesinambungan dan kesatuan kepolisian dalam meningkatkan upaya menanggulangi penyalahgunaan narkotika baik secara umum maupun secara perantara. 


\section{Upaya pembinaan}

Anak yang sudah pernah terk ait dalam penyalahgunaan narkoba hanya dapat dimintai keterangan dalam jangka waktu $1 \times 24$ jam setelah itu dikembalikan kepada keluarga untuk diberi pembinaan tetapi masih dibawah pengawasan kepolisian agar pembinaan tersebut berjalan dengan baik. Dalam pembinaan yang diakukan terhadap anak yang pelaku penjual beli nark oba adalah diperlukan pembinaan kemandirian dan pembinaan ketrampilan.

Di indonesia diperlukan penanggulangan dalam kejahatan ini karena hal ini mengakibatkan cenderung meluas dan meresahkan banyak masyarakat termasuk keluarga . Hal ini diperlukan dari kebijakan pemerintah supaya tidak semakin meluas dan penagak hukum semakin menyelesaikan permasalahan ini secara tuntas dan untuk ini sangat diperlukan penanggulangan dan pengawasan yang ketat agar diketahui oleh setiap orang tua, pekerja sosial dan semua pene gak hukum ditingkat-tingkat daerah. Salah satu cara dalam penganggulangan kejahatan yang sangat serius ini adalah didirikan balai penanggulangan terkhusus buat anak- anak penerus bangsa. Didirikannya balai penanggulangan ketergantungan narkoba perlu dorongan orang tua, tenaga medis, para pendidik terkhusus menganalisa perkembangan watak dan kepribadian bagi remaja. Pemerintah dalam penanggulangan masalah bahaya narkotika diperlukan pengikutsertaan masyarakat meningkatkan pengawas an dan diberikannya bimbingan kepada anak-anak yang sudah beranjak dewasa.

Upaya penegak hukum harus mengambil langkah-langkah yang cukup memadai didalam mengupayakan penganggulangan peredaran narkotika yang melibatkan remaja. Didalam pasal
53 Undang- undang, No.22 Tahun 1997 tentang narkotika. bahwa pemerintah mengupayakan kerja sama dengan bilateral, multilateral dengan beberapa negara lain yang bergunan untuk dapat mencegah serta membrantas melalui kepentingan nasional untuk penyalahgunaan dan peredaran gelap narkotika dengan. Berlakunya un dangundang No 22 Tahun 1997 tentang narkotika sangat berfungsi untuk salah satu upaya pencegahan sehingga tidak menyalahgunakan narkotika di indonesia dapat juga ditindak lanjuti dan bagi siapa yang melanggar akan diberikan sanksi pidana yaitu penjara atau denda yang cukup tinggi.

Ketentuan mengenai pidana naka terdapat didalam UU No 11 Tahun 2012 mengenai sebuah sistem peradilan anak, sanksi yang dijatuhkan kepada anak berupa Pidana pokok bagi anak, yang terdiri dari :

a. Pidana peringatan

b. Pidana dengan adanya syarat

1. Pelayanan kepada masyarakat

2. Pemidanaan diluar lembaga terkait

3. Serta melaui Pengawasan

c. Pelatihan kerja

d. Pembinaan dalam lembaga

e. Penjara.

\section{c. Pertimbangan Hakim Terhadap Tindak Pidana Pengedar Ganja Yang Telah Dilakukan Oleh Anak Melalui Studi Kasus Putusan : No. 10. Pid. Sus. Anak/ 2015/ Pn. Stb}

\section{Kronologi Kasus}

MUHAJIR ALIAS BULEK,

Berlokasi di depan pos lantas polsek gebang dijalan lintas Su matera Utara Dusun III Desa Paluh manis kecamatan gebang kabupaten langkat,pada hari kamis tanggal 15 
oktober 2015 pada pukul 04.30 wib yang tidak ada hak atau melawan hukum membawa, mentransit, mengirim, mengangkut, Narkoba Golongan I yang beratnya melebihi 1 kilogram dalam bentuk tanamgn atau melebihi 5 batang pohon beratnya melebihi 5 gram. Pada waktu itu bermula ketika saksi Nazli, Anggiat simajuntak dan Aldoft Simajuntak bersama personik polsek gebang melakukan sweeping terhadap kendaraan yang berlalu lalang. Anak Muhajir alias bulek duduk dan saksi meminta anak itu membuka tas ransel hitam. Saat ransel hitam dibuka ditemukan 4 bal narkotika dibalut lakban kuning narkotika golongan I jenis ganja kering. Dan anak ini juga menyimpan 11 bal narkotika jenis ganja yang dibalut dengan lakban kuning. 15 bal ganja kering dibawa dari sawang (aceh) menuju Medan ujar anak tersebut, ganja tersebut milik hamdan (DPO) anak mengaku hanya bertugas sebagai kurir dengan upah Rp.100.000 (seratus ribu rupiah) per $\mathrm{kg}$ atauperbalnya

\section{Putusan pengadilan}

a. Menyatakan Muhajir Alias Bulek telah terbukti secara sah dan menyakinkan bersalah melakukan tindak pidana

b. Menjatuhkan pidana kepada Muhajir Alias Bulek dengan pidan penjara selama kurang lebih 4 (empat) tahun dan dendasenilai Rp. 1.000.000.000,-(satu milyar rupiah) dengan ketentuan memberikan ketentuan apabila anak tidak sanggupmembayar denda maka akan diganti dengan menjalani pelatihan kerja selama 2 bulan

c. Menetapkan masa penangkapan yang telah dijalani oleh anak tersebut

d. Memerintahkan anak Muhajir Alias Bulek tetap ditahan e. Biaya perkara dibebani kepada anak sebesar Rp.2.000, (dua ribu rupiiah)

\section{Analisis Putusan}

No.10/pid.sus/2015/Pn.Slb

Didalam putusan No

10/pid.sus/2015/Pn.Stb dengan

mempertimbangkan fakta hukum yang ada. kepada anak Muhajir Bulek Hakim menjatuhkan putusan terbukti secara sah bersalah dalam melakukan sebuah tindak pidana tanpa hak dan telah melawan hukum dengan menjadi perantara jual beli Narkoba golongan I. Hakim memberi dakwaan alternatif dari jaksa penuntut umum yang sebagaimana dalam dakwaan pasal 114 ayat 2 Undang-undang RI No.35 Tahun 2009 tentang narkotika, dan tentang Narkotika, Undang- undang No.11 Tahun 2012 Tentang peradilan anak. Dan dijatuhkan pidana penjara selama 4 Tahun dan dan jika anak tidak dapat membayar denda tersebut akan diganti dengan pelatihan selama 2 bulan didenda sebesar Rp. 1.000.000.000., (satu milyar rupiah).

Pertimbangan hakim dari dakwaan alternatif dari jaksa penuntut umum, adalah berikut unsur-unsur sebagai berikut

a. Setiap orang barang siapa sebagaimana diatur dalam kitab undang-undang hukum pidana. Bahwa yang dimaksud dengan setiap orang adalah sebagai subjek hukum yang berupa perorangan maupun badan hukum yang diawili oleh perorangan yang menampakkan daya pikir sebagai persyaratan kemampuan bertanggung jawab.

b. Tanpa hak melawan hukum menyimpan dan mengusai atau disebut telah menyediakan Narkotika Golongan. I Jenis ganja yang dilakukan oleh Anak 
Bahwa unsur ini telah mengatur perbuatan yang dilarang yang bersifat alternatif sehubungan dengan peredaran narkotika golongan I. Dalam kaitannya dengan UU No. 35 Tahun 2009 a dalah tanpa izin dan persetujuan dari instan si yang berwenang. Dalam putusan No 10/pid.sus./2015/PN.Stb penulis tidak setuju dalam penjatuhan pidana oleh hakim tidak seharusnya anak dibawah umur dipidana penjara selama 4 (empat) Tahun, hal ini tidak menunjukkan upaya perlindungan hukum terhadap anak. Penjatuhan pidana terhadap anak dibawah umur akan mengakibatkan kerugian bagi perkembangan jiwa anak dimasa yang akan datang.

\section{SIMPULAN DAN SARAN}

\section{Simpulan}

1 Faktor terjadinya pengedaran narkotika golongan I yang dilakukan oleh anak dibawah umur atau disebut faktor in ternal dan faktor eksternal.

2 Upaya hukum yang dilakukan oleh aparat terhadap kejahatan pengedaran narkotika golongan I dilakukan dengan 3 cara yaitu, upaya preventif, upaya refresif, upaya pembinaan.

3. Didalam No10pid.sus.2015/PN/Stb penjatuhan pidana terhadap anak tidaklah tepat karena tidak menunjukan perlindungan terhadap anak.

\section{Saran}

1. Seharusya perlu pengawas dan pembinaan yang ketat dari orang tua terhadap anak dan selalu melihat perkembangan terhadap anak

2. Sebaiknya pemerintah memberikan bantuan badan pengawas yaitu Lembaga
Pembinaan Khusus Anak. dan membuat program pendidikan dan pembinaan yang diawasi oleh Balai Pemasyarakatan

3. Kebijakan oleh hakim dalam memutuskan perkara dengan putusan

No.10/pid.sus/2015/PN.Stb tidak tepat karena dapat menimbulk an kerugian bagi anak dimasa yang akan datang.

\section{DAFTAR PUSTAKA}

\section{a. Buku}

Chairul Huda, 2016, Dari Tiada Pidana Tanpa Kesalahan Menuju Kepada Tiada Pertanggungjawaban Pidana Tanpa kesalahan, Jakarta.

Gatot Supramono, 2017, Hukum Narkoba Indonesia, Jakarta.

Maidun, 2014, perlindungan hukum terhadap anak, Bandung.

Peter Mahmud Marzuki, 2005, Penelitian Hukum, Jakarta.

Juliana dan Sutrisna, 2018, Narkoba, Psikotropika dan Gangguan Jiwa, Yogyakarta.

Satoso, Topo, 2011, Kriminologi, Jakarta

H. Dadang Hawari, 2017, Penyalahgunaan \& ketergantungan Naza. Jakarta.

Rachman hendrawan, 1998, penyalahgunaan narkotika oleh remaja, Bandung.

Setiyawati,dkk, 2015, Buku Seri Bahaya Narkoba, Surakarta .

\section{b. Peraturan Undangan}

Undang-undang No.22 Tahun 1997 tentang narkotika

UU No. 11 Tahun 2012 tentang sistem peradilan anak

\section{c. INTERNET}

https://www.hukumonline.com/klinik/de 
tail/ulasan/lt5 1beb81b14ffe/jerathukum-bagi-pelajar-yang-

menggunakan-ganja/ diakses

tanggal 18 april 2020 